\title{
PERAN MITRA STRATEGIS DAN AGEN PERUBAHAN DALAM MANAJEMEN TALENTA DAN KINERJA MANAJER
}

\author{
Ida Ketut Kusumawijaya \\ STIE Triatma Mulya, Bali \\ E-mail: idaketut_kusumawijaya@yahoo.co.id
}

\begin{abstract}
The purposes of the study are to analyze: (1) characteristic of strategic partner and change agent roles, talent management and managers performance, (2) influence of strategic partner and change agent roles to talent management and its impact to managers performance. Four hundred hotel managers in Bali were participated in this study by using proportional random sampling. Data were analyzed using descriptive analysis and SEM. The result shows that: (1) strategic partner and change agent role, talent management and managers performance are in enough category, (2) positive and significant effect between strategic partner and change agent roles to talent management and its impact to managers performance.
\end{abstract}

Keywords: Strategic Partner Role, Change Agent Role, Talent Management, Managers Performance.

\begin{abstract}
Abstrak
Tujuan penelitian ini adalah untuk menganalisis: (1) karakteristik dari mitra strategis dan peran agen perubahan, manajemen bakat dan kinerja manajer, (2) pengaruh mitra strategis dan peran agen perubahan untuk manajemen bakat dan dampaknya terhadap kinerja manajer. Sebanyak empat ratus manajer hotel di Bali berpartisipasi dalam penelitian ini dengan menggunakan proporsional random sampling. Data dianalisis menggunakan analisis deskriptif dan SEM. Hasil penelitian menunjukkan bahwa: (1) mitra strategis dan peran agen perubahan, manajemen bakat dan kinerja manajer termasuk dalam kategori cukup, (2) pengaruh positif dan signifikan antara mitra strategis dan peran agen perubahan untuk manajemen bakat dan dampaknya terhadap kinerja manajer.
\end{abstract}

Keywords: Peran Mitra Strategis, Peran Agen Perubahan, Manajemen Talenta, kinerja Manajer.

\section{PENDAHULUAN}

Saat ini peran dan tanggungjawab manajer mengalami pergeseran, perhatian lebih besar pada peran mitra strategis (Ulrich, 1997), yang dapat memberikan nilai tambah bagi strategi organisasi dalam menghadapi perubahan lingkungan bisnis dan meningkatkan keunggulan bersaing. Peran mitra strategis membutuhkan pengetahuan, kemampuan dan partisipasi program manajemen sumber daya manusia strategis dalam mendukung strategi organisasi (McCracken and Wallace, 2000; Gill et al. 2004). Margaret (2001) menjelaskan bahwa peran mitra strategis manajer merupakan formulasi peran strategik manajer secara menyeluruh dari berbagai aspek mengacu pada strategi organisasi dalam rangka memperbaiki kinerja organisasi (Mello, 2002; Dessler, 2006; Christensen, 2006; Armstrong, 2006; Ivancevich, 2006; Noe, 2006). Menurutnya peran mitra strategis manajer dipengaruhi oleh: (a) fokus pada pelanggan, (b) budaya dan kepemimpinan, (c) supervisi manajer, (d) lingkungan kerja, (e) keterlibatan manajer dan teamwork, (f) pelatihan dan pengembangan, (g) evaluasi dan perbaikan kinerja, (h) faktor pemilihan pekerjaan, (i) iklim pelayanan.

Survei awal mengungkapkan bahwa peran mitra strategis manajer pada hotel berbintang di Bali belum sepenuhnya disadari dan dilaksanakan dan secara keseluruhan berada pada kategori rendah, hal ini dikhawatirkan akan menjadi kendala dan tantangan yang perlu mendapat perhatian serius 
pihak manajemen hotel berbintang di Bali. Padahal industri perhotelan menilai investasi pada SDM sangat penting dalam memberikan peran mitra strategis kepada manajer agar memiliki kemampuan lebih dalam memahami dan ikut serta merancang strategi organisasi, berdasarkan pengelolaan kinerja SDM terbaik dalam menghadapi perubahan lingkungan bisnis dan meningkatkan keunggulan bersaing. (Philmore, et al., 2006; Dan-Shang and ChiLih, 2008; Jeanette, 2009).

Pada sisi lain manajer juga berperan sebagai agen perubahan yang akan merancang dan mengelola kapasitas perubahan dan perubahan budaya organisasi (Ulrich, 1997). Untuk itu manajer dalam hal ini harus menguasai 4 C Chris. 2007), yaitu: competence, commitment, cost effectiveness dan congruents. Sebagai agen perubahan manajer juga perlu menguasai empat agenda (Ulrich, 1997), yaitu: (a) katalisator/ /sponsor, (b) fasilitator, (c) perancang, (d) demonstrator.

Paul (2002) menjelaskan bahwa peran agen perubahan manajer merupakan kemampuan mentransformasikan potensi yang dimiliki manajer untuk mengelola perubahan budaya organisasi, kemampuan untuk memperbaiki rancangan, implementasi inisiatif dan mengurangi siklus waktu pada seluruh aktivitas organisasi. Faktor yang mempengaruhi peran manajer sebagai agen perubahan sebagai berikut: (a) menentukan perubahan, (b) mengelola kendala perubahan, (c) mengidentifikasi pendekatan implementasi perubahan, (d) meningkatkan dukungan untuk berubah, (e) mengembangkan sasaran perubahan, (f) menciptakan budaya yang sesuai, (g) membangun kapasitas sebagai agen perubahan, (h) perencanaan motivasi, (i) perencanaan komunikasi.

Survei awal yang lain juga mengungkapkan bahwa peran agen perubahan manajer pada hotel berbintang di Bali belum sepenuhnya disadari dan dilaksanakan dan secara keseluruhan peran agen perubahan manajer berada pada kategori rendah, hal ini menjadi kendala dan tantangan yang perlu diperhatikan dan dikelola dalam menciptakan daya saing hotel untuk menawarkan kualitas pelayanan unggul seiring meningkatnya persaingan global. Padahal Anne 2002 mengungkapkan bahwa manajer seharusnya memiliki kemampuan mengelola perubahan sehingga dapat menghasilkan nilai tambah bagi perusahaan, memahami mengapa organisasi harus siap terhadap perubahan (Lancourt and Savage, 2005). Manajer mengerti proses penting untuk perubahan, membuat komitmen dan menjamin bahwa perubahan sungguh terwujud, mampu beradaptasi dan mengadopsi perubahan dalam menciptakan keunggulan bersaing (Daul 2003; Sammi, 2004; Anita, 2009).

Manajemen talenta pertama kali diperkenalkan oleh McKinsey and Company pada pertengahan 1990-an. Lorenzo (2005) menjelaskan manajemen talenta adalah pengelolaan sumber daya manusia dengan menarik, mengembangkan dan mempertahankan SDM secara terintegrasi sehingga dapat memastikan bahwa the right people with the right skills are in the right place dalam proses pencapaian kinerja organisasi (Michaels et al. 2001; Berger and Berger, 2003; Sparrow et al. 2004; Bouderau and Ramstad, 2007; Bill and Marcus, 2007). Menurutnya faktor yang mempengaruhi manajemen talenta: (a) strategi mempertahankan SDM, (b) strategi pemilihan SDM, (c) stategis pelatihan, (d) keberadaan SDM dalam organisasi, (e) keinginan SDM untuk tetap bekerja di organisasi, (f) penerimaan kinerja organisasi.

Selanjutnya, survei awal yang lain mengungkapkan bahwa partisipasi manajer dalam manajemen talenta pada hotel berbintang di Bali belum sepenuhnya disadari dan dilaksanakan dan secara keseluruhan partisipasi manajer dalam manajemen talenta berada dalam kategori rendah. Hal menjadi kendala dan tantangan yang harus diperhatikan dan dihadapi oleh pihak manajemen hotel berbintang di Bali. Padahal Watson (2007) menyebutkan meningkatnya permintaan dan kebutuhan akan SDM bertalenta menjadi perhatian penting bagi organisasi (Gillian and Samantha, 2008). Tantangan yang dihadapi organisasi dalam pengelolaan SDM agar berkembang dan dapat meningkatkan kinerja yakni dengan fokus pada program manajemen talenta (Matthew et al. 2006; Josh, 2008; Julia and Evelina, 2008; Sandra, 2008). Begitupula Tom (2008) menyatakan manajemen talenta dalam industri perhotelan menjadi mindset organisasi yang akan membutuhkan superior talent, yang menjamin the right people with the right jobs at the right time, based on strategic 
business objectives sebagai driver of competitive advantage (Michael, 2007; Paul, 2008; Norma, 2008; Bernadettev and Sheetal, 2008; Margaret, 2008).

Kinerja karyawan menurut Gomes (2001) merupakan catatan outcome yang dihasilkan dari suatu fungsi pekerjaan atau kegiatan tertentu selama suatu periode waktu tertentu yang menunjukkan seberapa baik seorang manajer dalam melaksanakan pekerjaannya (Benardin and Russell, 2003; Cascio, 2006; Robbin, 2006; Dessler, 2006; Noe et al. 2006). Menurutnya faktor penilaian terhadap kinerja karyawan yaitu: (a) Quantity of work, (b) Quality of work, (c) Job knowledge, (d) Creativeness, (e) Cooperation, (f) Dependability, (g) Initiative, (h) Personal qualities.

Survei juga mengungkapkan bahwa kinerja manajer hotel berbintang di Bali belum sepenuhnya disadari dan dilaksanakan dengan baik dan secara keseluruhan kinerja manajer berada pada kategori rendah. Hal ini menandakan bahwa ternyata masih dibutuhkan peningkatan kinerja manajer guna menciptakan real competitive advantage bagi hotel. Padahal Mohinder and Anastasia (2007) menyebutkan bahwa organisasi mengelola SDM untuk mengembangkan seluruh potensi yang dimiliki SDM untuk menciptakan kinerja yang baik, dengan menggunakan indikator penilaian kinerja karyawan, sehingga tercipta kinerja karyawan yang baik (May et al. 2004). Mine and Peter (2005) menyebutkan bahwa banyak hotel menilai pengukuran kinerja manajer adalah penting, merefleksikan seluruh lingkungan kerja yang ada dalam hotel termasuk penilaian employees as well as guests (Helen and Jackie, 2001; Bob, 2004; Pauline and Geraldine, 2007).

Penelitian ini bertujuan untuk menghasilkan suatu kajian tentang peran mitra strategis dan agen perubahan, partisipasi manajer dalam manajemen talenta dan kinerja manajer dan mengkaji pengaruh peran mitra strategis dan agen perubahan terhadap manajemen talenta serta dampaknya pada kinerja manajer pada hotel berbintang di Bali.

\section{KAJIAN PUSTAKA}

\section{Peran Mitra Strategis}

Sumber daya manusia adalah mitra strategis untuk memastikan dan menciptakan organi- zational diagnosis dengan melaksanakan langkah dalam organisasi yaitu: menetapkan sistem yang mendasari organisasi; merubah desain ke dalam suatu penilaian kelemahan dan kekuatan organisasi sehingga rencana tindakan organisasi menjadi kenyataan; melaksanakan penilaian untuk perbaikan bagi SDM guna menambah nilai perusahaan melalui perubahan budaya, kompetensi governance (desain organisasi, kebijakan, dan komunikasi), proses kerja (pembelajaran dan perubahan), dan kepemimpinan; memusatkan perhatian pada hal yang dianggap penting dari isu organisasi dan mengevaluasi kegiatan pengelolaan SDM sebagai prioritas paling tinggi (Ulrich, 1997).

Menurut Dessler (2006) menyebutkan bahwa manajemen SDM strategi memiliki keterkaitan antara pengelolaan peran strategis SDM dengan tujuan organisasi untuk meningkatkan kinerja bisnis dan mengembangkan budaya organisasi dan menjaga fleksibilitas dan inovasi. (Christensen, 2006; Armstrong, 2006; Ivancevich, 2006; Noe et al, 2006; Mello, 2002).

David (2007) mengatakan bahwa dewasa ini organisasi menghadapi kompleksitas pengelolaan SDM dalam membangun organisasi global yang efektif. Satu alternatif adalah dengan menyediakan SDM dengan kemampuan strategis, memiliki wawasan dan pengalaman global dan keterampilan yang dibutuhkan untuk menjadi strategic partner dan efektif untuk bisnis masa datang. (Sharon 2007; Fiona 2007; Don et al. 2007; Kathy 2006; Anonymous, 2006; ohn, 2005; Margaret, 2001).

\section{Peran Agen Perubahan}

Peran agen perubahan merancang dan mengelola kapasitas perubahan dan perubahan budaya (Ulrich, 1997). Ada lima hal yang menantang organisasi dalam perubahan yaitu: (1) globalisasi, (2) profitabilitas melalui pertumbuhan, (3) teknologi, (4) modal intelektual, (5) berubah, berubah dan terus berubah. Untuk menghadapinya organisasi dituntut untuk membangun kapabilitas yang baru yakni dengan mengelola core assets dan core activities (Anita, 2009). Oleh karenanya SDM dalam organisasi akan terlibat proses perubahan yang menyangkut dimensi (Paul, 2002): (1). Defining the Change, (2). Removing historical 
barriers, (3). Indentifying the change implementation approach, (4). Generating sponsorship for change, (5). Develop target readiness, (6). Creating cultural fit, (7). Building agen perubahan capacity, (8). Motivation planning, (9). Communication planning.

Chris (2007) mengatakan bahwa bisnis yang sukses dimasa depan akan membutuhkan usaha untuk mendapatkan dan memberdayakan SDM yang terbaik dengan membangun hubungan dengan pelanggan. Perubahan peran SDM inilah yang akan dapat bertahan dimasa mendatang sebagai agen perubahan. Peten 2004; Sammi 2004; Pau, 2003; Anne 2002; Robert 2001).

\section{Manajemen Talenta}

Istilah manajemen talenta bermaksud memaksimalkan kinerja sumber daya manusia dan organisasi dalam pencapaian potensi terbaiknya menghadapi tantangan bisnis. (Amy, 2007; Parminder, 2009; Boudreau dan Peter., 2007; Berger and Berger; 2003; Michaels et al. 2001; Bill and Marcus, 2007; Sparrow et.al. 2004)

Strategi manajemen talenta pada perusahaan seharusnya disesuaikan dengan visi, tujuan, dan strategi perusahaan, agar SDM perusahaan dapat secara dinamis pula menyesuaikan strategi bersaing menghadapi perubahan lingkungan bisnis. (Carol, 2004; Jyotsna, 2007). Saat ini perkembangan manajemen talenta sendiri meningkat pesat. Konsep Talent Based Human Resouce Management (TBHRM) perlahan tapi pasti dinilai banyak praktisi sebagai konsep yang lebih lengkap dan menyeluruh. Manajemen talenta dapat meningkatkan produktivitas dan kepuasan kerja karyawan dalam mecapai business performance yang diharapkan (Taleo, 2006; Michiel and Jan, 2005; Ian, 2007; Rakesh and Jyotsna, 2009).

Peters (2006) menyebutkan bahwa di era ketika value added tercipta dari kreatifitas, keunikan, semangat, keterlibatan SDM bertalenta menjadi basis utama competitive advantage, seluruh bagian organisasi harus mencerminkan diri mereka sendiri sebagai organisasi yang well talented management (Boudreau, 2003; Karen. 2007; Ian, 2007; Jyotsna, 2007; $\operatorname{Rod} 2007$; $\operatorname{Eav}$ 2007; Rebecca, 2006; Chris, 2007; Alison et al. 2006; Guy et al. 2007; Lorenzo, 2005).

\section{Kinerja Manajer}

Untuk mengetahui kinerja manajer berbagai faktor perlu dipertimbangkan dalam menilai kinerja manajer. Cascio (2006) mengatakan bahwa penilaian kinerja adalah evaluasi kinerja karyawan secara sistematik berhubungan dengan kekuatan dan kelemahan individu atau kelompok yang dikaitkan dengan kinerja standar. Tiga kualifikasi penting bagi pengembangan kriteria kinerja yang dapat diukur secara obyektif, yaitu: (1) relevancy, (2) reliability, dan (3) discrimination (Dessler, 2006; Bernarddin and Russel, 2003; Noe, 2006; Howard. 2007).

Susan (2007), menjelaskan bahwa proses penilaian kinerja seperti praktek tradisional dilaksanakan secara mendasar sebagai value-based, vision-driven, missionoriented. Tidak ada sistem penilaian kinerja yang sempurna, dan tidak ada sistem secara sempurna dapat dipercaya dalam mengukur kineria karyawan (Ann. 2007; Laurie 2007; David 2007; Judded al. 2006).

\section{Kerangka Pemikiran}

\section{Keterkaitan peran mitra strategis terhadap manajemen talenta}

Peran mitra strategis menjadi perdebatan dalam implementasi pengelolaan SDM di dalam organisasi. Hal ini muncul berkenaan dengan nilai yang diciptakan peran mitra strategis SDM dalam organisasi yang mempengaruhi isu sentral SDM yang banyak dibicarakan, yaitu: talent management, performance management, alignment of human capital. David 2007; Marcus 2007; Andrew and Matthew 2006; Malcolm 2006; Phil and Shaun, 2005; Drehen 2001; Andrew 2005; Anonymous, 1999). Rumusan hipotesis keterkaitan peran mitra strategis terhadap manajemen talenta adalah sebagai berikut:

H1: Peran mitra strategis berpengaruh terhadap manajemen talenta pada hotel berbintang di Bali.

\section{Keterkaitan peran agen perubahan terhadap manajemen talenta}

Hubert (2006) menjelaskan bahwa sebelum perubahan budaya dalam organisasi bisa efektif, seharusnya lakukan perencanaan perubahan terlebih dahulu. Pertama dimulai dengan self- 
learning dan self-knowledge sebagai wujud peran agen perubahan untuk mengimplementasikan konsep personal balance scorecard (PBSC) dan organizational balance scorecard (OBSC), sehingga perubahan yang direncanakan akan bisa terlaksana dengan baik. Integrasi tersebut dipaparkan lewat PBSC dan OBSC dalam proses pengembangan kompetensi dan akhirnya akan menghasilkan efektifitas manajemen talenta. Elissa Tina and Nidhil 2005; Anonymous, 2007; Edward 2005; Chervl 2005; Anonymous, 2005; Ulrich, 1997). Rumusan hipotesis keterkaitan peran agen perubahan terhadap manajemen talenta adalah sebagai berikut:

H2: Peran agen perubahan berpengaruh terhadap manajemen talenta pada hotel berbintang di Bali.

\section{Keterkaitan peran mitra strategis dan agen perubahan terhadap manajemen talenta}

Lea (2004) menjelaskan bahwa organisasi menghadapi kompleksitas tantangan yang mengancam dimasa depan. Persiapan untuk menghadapi hal tersebut yaitu dengan ikutserta berperan dalam dinamika perubahan keputusan pengelolaan strategis SDM yang berkaitan dengan tujuan strategis organisasi agar dapat meningkatkan manajemen talenta organisasi untuk menghadapi perubahan lingkungan dan mencapai kinerja unggul organisasi. Drehen 2001; Anonymous, 2006; oan 2004; Malcolm 2006; Elissa Tina and Nidhi 2005; Edward 2005). Rumusan hipotesis keterkaitan peran mitra strategis dan agen perubahan terhadap manajemen talenta adalah sebagai berikut:

H3: Peran mitra strategis dan agen perubahan berpengaruh terhadap manajemen talenta pada hotel berbintang di Bali.

\section{Keterkaitan peran mitra strategis dan agen perubahan terhadap manajemen talenta serta dampaknya pada kinerja manajer}

Dreher (2001) menjelaskan bahwa perubahan yang terjadi pada strategi bisnis akan dapat berdampak pada praktek strategi SDM. Oleh karenanya dibutuhkan kesesuaian fungsi strategi SDM dengan strategi bisnis dengan tetap berperan menjadi agen perubahan. Pengelolaan peran SDM dalam perubahan akan secara signifikan mempengaruhi kegiatan pengelolaan talenta organisasi dan memberikan perhatian pada kinerja SDM dan strategi organisasi serta nilai inti organisasi. Dan hubungan antara strategi SDM dengan strategi bisnis hanya dapat dibuat dengan analisis perubahan lingkungan internal dan eksternal organisasi dalam peran sebagai agen perubahan pada bisnis. (Lea 2004; Elissa Tina and Nidhi. 2005; Anonymous, 2006; Malcolm. 2006; Andrew Matthew 2006).

Hal ini diperkuat oleh penelitian yang dilakukan Ioan (2004) mengemukakan bahwa untuk dapat berhasil, sebuah organisasi bisnis memerlukan perencanaan SDM. Dan SDM tersebut berperan sebagai mitra strategis untuk mengembangkan keterampilan dan kompetensi bisnis. Perencanaan SDM harus berdasarkan kepercayaan, sehingga dapat efektif dan mampu beradaptasi dengan cepatnya perubahan. Pada peran seperti ini SDM sebagai mitra strategis dan agen perubahan, karena pengelolaan SDM selalu berubah. Peran mitra strategis dan agen perubahan ini faktor yang mempengaruhi pengelolaan talenta organisasi yang memegang peran yang sangat signifikan dalam menghadapi tantangan kinerja bisnis jangka panjang. (Michae, 2003: Phil and Shaun 2005; Andrew 2005; Edward 2005; Cindy and Michael, 2006). Rumusan hipotesis keterkaitan peran mitra strategis dan agen perubahan terhadap manajemen talenta serta dampaknya pada kinerja manajer adalah sebagai berikut:

H4: Peran mitra strategis dan agen perubahan berpengaruh terhadap manajemen talenta dan memiliki dampak pada kinerja manajer pada hotel berbintang di Bali.

\section{METODE PENELITIAN}

\section{Operasionalisasi Variabel}

Penelitian ini mengacu pada peran mitra strategi yang diungkapkan Margaret (2001) terdiri dari 8 dimensi dan diukur dengan skala likert sebanyak 15 pertanyaan. Variabel peran agen perubahan yang diungkapkan Paul (2002) terdiri dari 9 dimensi dengan 17 item pertanyaan skala likert.

Sedangkan variabel manajemen talenta mengacu pada Lorenzo (2005) yang meliputi 6 dimensi dengan 16 pertanyaan dalam skala likert. Selanjutnya variabel kinerja manajer dari Gomes (2001) menyangkut 8 dimensi dengan 16 item pertanyaan skala likert. 


\section{Sumber Dan Cara Penentuan Data}

Populasi penelitian ini adalah manajer hotel berbintang di Bali, dengan jumlah sampel sebanyak 400. Pengambilan sampel dengan metode acak proporsional (Proportional Random Sampling), dengan ketentuan sampel adalah manajer dari tingkat supervisor sampai tingkat manajer departemen. Cara penentuan data dalam penelitian ini adalah data primer melalui penyebaran kuesioner, wawancara langsung dengan responden. Sedangkan data sekunder diperoleh dari kantor Dinas Pariwisata dan Budaya Bali, Kantor Biro Pusat Statistik Bali, dan Hotel berbintang di Bali.

\section{Pengujian Instrumen Penelitian}

Dalam penelitian ini pengumpulan data dilakukan dengan menggunakan instrumen kuesioner, oleh karena itu instrumen penelitian perlu diuji coba pada responden yang lain untuk mengetahui tingkat validitas dan reliabilitas.

\section{Teknik Analisis}

Analisis dan interpretasi data dalam penelitian ini dengan menggunakan metode kualitatif dan kuantitatif. Metode kualitatif berupa deskriptif data yang masuk dengan analisis distribusi frekuensi dan diberi penjelasan. Sedangkan metode kuantitatif berupa analisis hubungan antar variabel yang diteliti menggunakan alat analisis Structural Equation Modelling (SEM) (Hair et al., 2006).

\section{HASIL ANALISIS DAN PEMBAHASAN}

\section{Analisis Deskriptif Peran Mitra Strategis}

Kategori pelaksanaan peran mitra strategis manajer pada hotel berbintang di Bali (lampiran 1) menunjukkan bahwa hasil skoring untuk peran mitra strategis manajer secara total berada pada kategori cukup. Supervisi karyawan merupakan komponen yang lebih tinggi dalam pelaksanaan peran mitra strategis manajer dibandingkan dengan komponen lainnya. Hal ini dapat dilihat dari skor fokus pada pelanggan yang diperoleh berada pada kategori cukup, budaya dan kepemimpinan yang diperoleh berada pada kategori tinggi. Supervisi karyawan yang diperoleh berada pada kategori tinggi, lingkungan kerja yang diperoleh berada pada kategori cukup, keterlibatan karyawan dan timwork yang diperoleh berada pada kategori tinggi, pelatihan dan pengembangan yang diperoleh berada pada kategori cukup, evaluasi dan perbaikan kinerja yang diperoleh berada pada kategori cukup tinggi, faktor pemilihan pekerjaan yang diperoleh berada pada kategori cukup dan iklim pelayanan yang diperoleh berada pada kategori tinggi.

\section{Analisis Deskriptif Peran Agen Perubahan}

Kategori pelaksanaan peran agen perubahan manajer pada hotel berbintang di Bali (lampiran 2) menunjukkan bahwa hasil skoring untuk pelaksanaan peran agen perubahan manajer pada hotel berbintang di Bali termasuk dalam kategori cukup. Menciptakan budaya yang sesuai merupakan komponen yang lebih tinggi dalam pelaksanaan peran manajer sebagai agen perubahan dibandingkan dengan komponen lainnya. Hal ini dapat dilihat dari menentukan perubahan yang masuk kategori cukup, mengelola kendala perubahan yang masuk kategori cukup, pendekatan identifikasi implementasi perubahan yang masuk kategori cukup, meningkatkan dukungan untuk berubah yang masuk kategori cukup, mengembangkan sasaran perubahan yang masuk kategori cukup, menciptakan budaya yang sesuai yang masuk kategori cukup, membangun kapasitas sebagai agen perubahan yang masuk kategori cukup, perencanaan motivasi yang masuk kategori cukup dan perencanaan komunikasi yang masuk kategori cukup.

\section{Analisis Deskriptif Manajemen Talenta}

Kategori partisipasi manajer dalam manajemen talenta pada hotel berbintang di Bali (lampiran 3) menunjukkan bahwa hasil skoring untuk partisipasi manajer dalam manajemen talenta secara total masuk kategori cukup. Penerimaan kinerja organisasi yang lebih tinggi dalam partisipasi manajer dalam manajemen talenta dibandingkan dengan lainnya. Hal ini dapat dilihat dari strategi mempertahankan karyawan yang masuk kategori cukup, strategi pemilihan manajer yang masuk kategori cukup, strategi pelatihan karyawan yang masuk kategori cukup, keberadaan manajer di dalam organisasi yang masuk kategori cukup, keinginan manajer tetap bekerja di organisasi yang masuk kategori 
cukup dan penerimaan kinerja organisasi yang masuk kategori cukup.

\section{Analisis Deskriptif Kinerja Manajer}

Kategori partisipasi manajer dalam kinerja manajer pada hotel berbintang di Bali (lampiran 4) menunjukkan bahwa hasil skoring untuk partisipasi manajer dalam kinerja manajer secara total masuk kategori cukup. Pemahaman prosedur kerja yang lebih tinggi dibandingkan dengan lainnya. Hal ini dapat dilihat jumlah pekerjaan yang masuk kategori cukup, kualitas pekerjaan yang masuk kategori cukup, pemahaman prosedur kerja yang masuk kategori tinggi, kreativitas yang masuk kategori tinggi, kerjasama yang masuk kategori cukup, kemampuan mendelegasikan pekerjaan yang masuk kategori cukup, inisiatif yang masuk kategori cukup dan kualitas pribadi yang masuk kategori cukup.

\section{Analisis Pengaruh Peran Mitra Strategis Dan Agen Perubahan Terhadap Manajemen Talenta Serta Dampaknya Pada Kinerja Manajer}

Pengujian pengaruh peran mitra strategis dan agen perubahan terhadap manajemen talenta serta dampaknya pada kinerja manajer dapat dilihat pada Gambar 1.

Untuk menguji pengaruh Peran Mitra Strategis dan Agen Perubahan terhadap Manajemen Talenta digunakan uji t dengan kriteria uji untuk $\alpha$ penelitian sebesar 0,05 ; nilai untuk batas dinyatakan uji signifikansi adalah 1,965. Hasil perbandingan antara nilai $t$ hitung dengan $t_{\text {tabel }}$ untuk uji parsial dapat dilihat pada tabel 1 .

Jadi terdapat pengaruh peran mitra strategis terhadap manajemen talenta, terdapat pengaruh peran agen perubahan terhadap manajemen talenta, dan terdapat pengaruh peran mitra strategis dan agen perubahan terhadap manajemen talenta yang signifikan secara pengujian statistik karena nilai $t$ hitung untuk setiap pengujian lebih besar dari $\mathrm{t}$ tabel 1,965 .

Untuk menguji pengaruh Peran Mitra Strategis Dan Agen Perubahan Terhadap Manajemen Talenta Serta Dampaknya Pada Kinerja Manajer digunakan uji t dengan kriteria uji untuk $\alpha$ penelitian sebesar 0,05 ; nilai untuk batas dinyatakan uji signifikansi adalah 1,965. Hasil perbandingan antara nilai $\mathrm{t}_{\text {hitung }}$ dengan $\mathrm{t}$ tabel untuk uji parsial dapat dilihat pada tabel 2.

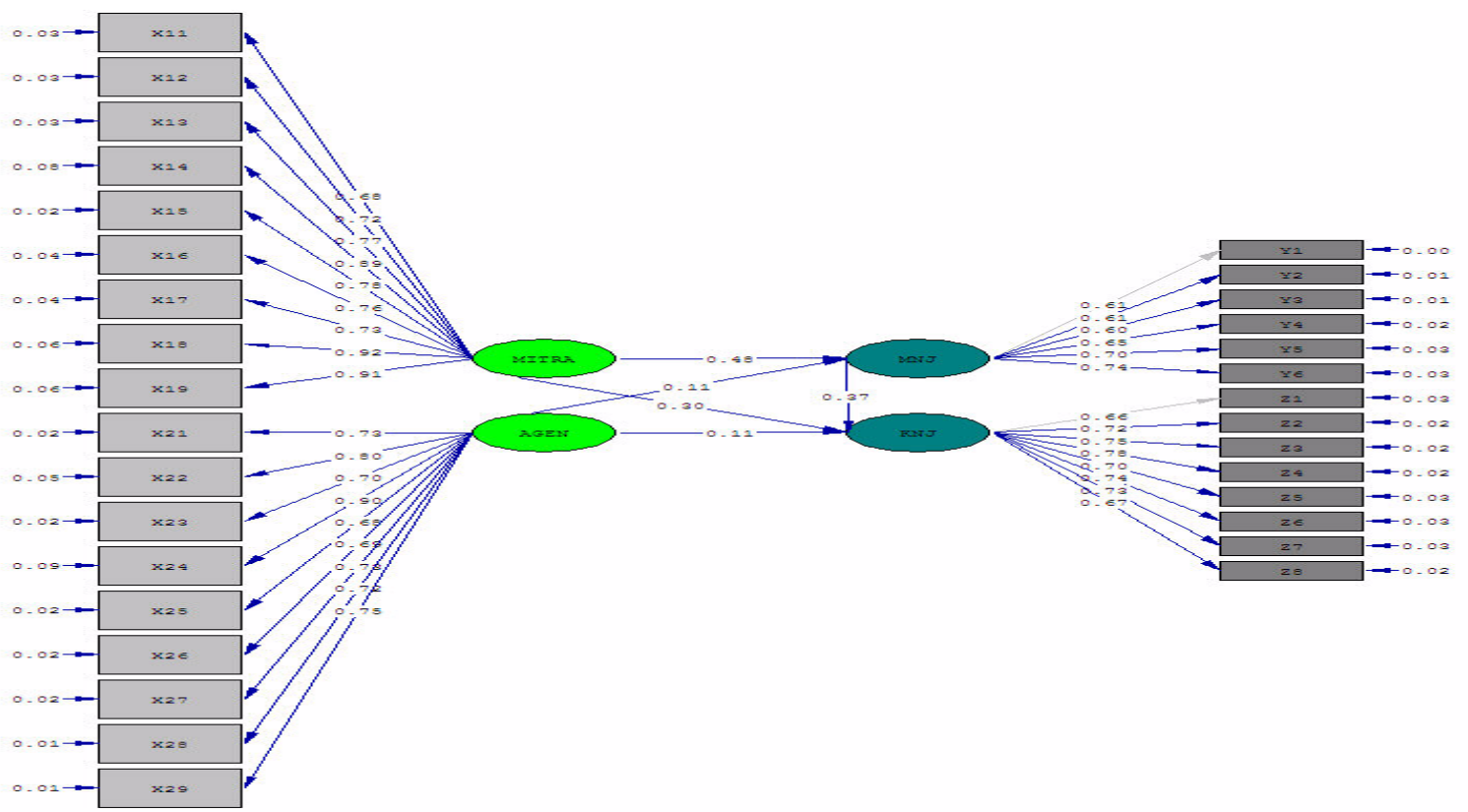

Gambar 1a: Path Diagram Model Struktural Pengaruh Peran Mitra Strategis Dan Agen Perubahan Terhadap Manajemen Talenta Serta Dampaknya Pada Kinerja Manajer

(nilai estimasi) 


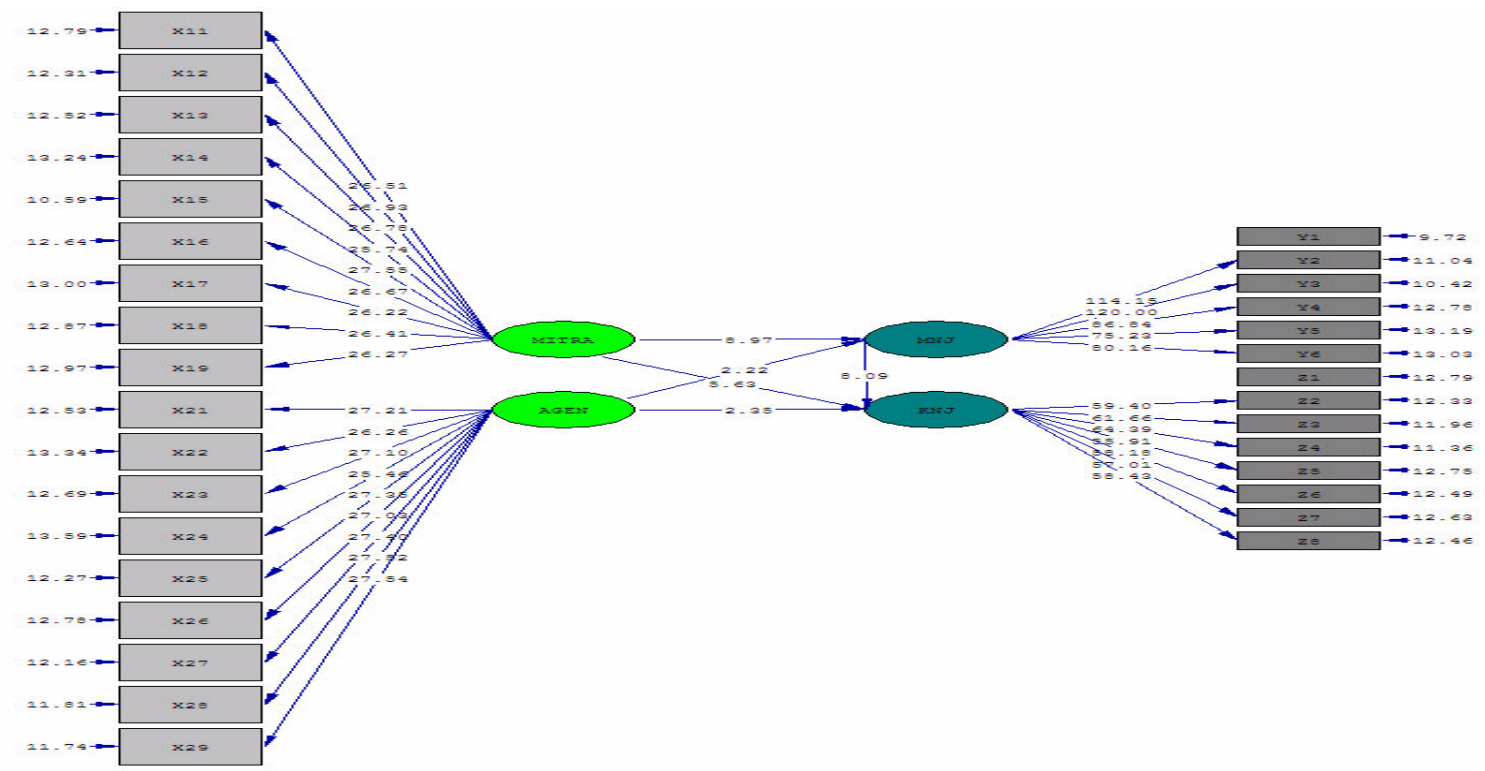

Gambar 1b: Path Diagram Model Struktural Pengaruh Peran Mitra Strategis Dan Agen Perubahan Terhadap Manajemen Talenta Serta Dampaknya Pada Kinerja Manajer (nilai $t_{\text {hitung }}$ )

Tabel 1: Uji Pengaruh Peran Mitra Strategis dan Agen Perubahan terhadap Manajemen Talenta

\begin{tabular}{|c|c|c|c|c|c|c|}
\hline No & Uji & $\begin{array}{c}\text { Koefisien } \\
\text { Jalur }\end{array}$ & $t_{\text {hitung }}$ & $t_{\text {tabel }}$ & Hasil & Kesimpulan \\
\hline 1. & $\begin{array}{l}\text { Peran Mitra Strategis } \\
\text { berpengaruh terhadap } \\
\text { Manajemen Talenta }\end{array}$ & 0.48 & 8.97 & 1.965 & $\begin{array}{c}\text { Uji } \\
\text { Signifikan }\end{array}$ & $\begin{array}{l}\text { Terdapat pengaruh Peran } \\
\text { Mitra Strategis terhadap } \\
\text { Manajemen Talenta }\end{array}$ \\
\hline 2. & $\begin{array}{l}\text { Peran Agen } \\
\text { Perubahan } \\
\text { berpengaruh terhadap } \\
\text { Manajemen Talenta }\end{array}$ & 0.11 & 2.22 & 1.965 & $\begin{array}{c}\text { Uji } \\
\text { Signifikan }\end{array}$ & $\begin{array}{l}\text { Terdapat pengaruh Peran } \\
\text { Agen Perubahan terhadap } \\
\text { Manajemen Talenta }\end{array}$ \\
\hline
\end{tabular}

Sumber : Hasil Pengolahan Data Penelitian.

Tabel 2: Uji Pengaruh Peran Mitra Strategis Dan Agen Perubahan Terhadap Manajemen Talenta Serta Dampaknya Pada Kinerja Manajer.

\begin{tabular}{|c|c|c|c|c|c|c|}
\hline No & Uji & $\begin{array}{c}\text { Koefisien } \\
\text { Jalur }\end{array}$ & $t_{\text {hitung }}$ & $t_{\text {tabel }}$ & Hasil & Kesimpulan \\
\hline 1. & $\begin{array}{l}\text { Peran Mitra Strategis } \\
\text { berpengaruh terhadap } \\
\text { Kinerja Karyawan }\end{array}$ & 0.30 & 5.63 & 1.965 & $\begin{array}{c}\text { Uji } \\
\text { Signifikan }\end{array}$ & $\begin{array}{l}\text { Terdapat pengaruh peran } \\
\text { Mitra Strategis terhadap } \\
\text { Kinerja manajer }\end{array}$ \\
\hline 2. & $\begin{array}{l}\text { Peran Agen } \\
\text { Perubahan } \\
\text { berpengaruh terhadap } \\
\text { Kinerja manajer }\end{array}$ & 0.11 & 2.35 & 1.965 & $\begin{array}{c}\text { Uji } \\
\text { Signifikan }\end{array}$ & $\begin{array}{l}\text { Terdapat pengaruh peran } \\
\text { Agen Perubahan terhadap } \\
\text { Kinerja manajer }\end{array}$ \\
\hline 3. & $\begin{array}{l}\text { Manajemen Talenta } \\
\text { berpengaruh terhadap } \\
\text { Kinerja manajer }\end{array}$ & 0.37 & 8.09 & 1.965 & $\begin{array}{c}\text { Uji } \\
\text { Signifikan }\end{array}$ & $\begin{array}{l}\text { Terdapat pengaruh } \\
\text { Manajemen Talenta } \\
\text { terhadap Kinerja manajer }\end{array}$ \\
\hline
\end{tabular}

Sumber : Hasil Pengolahan Data Penelitian.

Berdasarkan uji di atas dapat disimpulkan bahwa terdapat pengaruh peran mitra strategis terhadap kinerja manajer, terdapat pengaruh peran agen perubahan terhadap kinerja manajer dan terdapat pengaruh manajemen talenta terhadap kinerja manajer yang signifikan secara pengujian statistik karena nilai $t_{\text {hitung }}$ untuk setiap pengujian lebih besar dari $\mathrm{t}_{\text {tabel }} 1,965$. 
Berdasarkan hasil perhitungan diperoleh total pengaruh peran mitra strategis dan agen perubahan terhadap manajemen talenta serta dampaknya pada kinerja manajer adalah sebesar $0.4300(43.00 \%)$ dan pengaruh faktor lain sebesar $0.5700(57.00 \%)$. Pengaruh peran mitra strategis terhadap kinerja manajer adalah sebesar $16.95 \%$. Pengaruh peran agen perubahan terhadap kinerja manajer adalah sebesar $4.61 \%$. Pengaruh manajemen talenta terhadap kinerja manajer adalah sebesar 21.35\%. Rangkuman hasil Pengaruh Peran Mitra Strategis Dan Agen Perubahan Terhadap Manajemen Talenta Serta Dampaknya Pada Kinerja Manajer dapat dilihat pada tabel 3.

\section{PEMBAHASAN}

Hasil pengujian mengenai pengaruh peran mitra strategis dan agen perubahan terhadap manajemen talenta serta dampaknya pada kinerja manajer hotel berbintang di Bali menunjukkan adanya pengaruh yang bermakna dari ketiga variabel (peran mitra strategis dan peran agen perubahan serta manajemen talenta) terhadap kinerja manajer hotel berbintang di Bali. Secara total diperoleh $42.91 \%$ perubahan kinerja manajer hotel berbintang di Bali dapat dijelaskan oleh peran mitra strategis dan peran agen perubahan serta manajemen talenta.

Hal ini berarti peran mitra strategis dan peran agen perubahan dan manajemen talenta secara bersama berperan dalam upaya membentuk, mempertahankan dan meningkatkan kinerja manajer hotel berbintang di Bali. Dengan demikian pengaruh peran mitra strategis dan peran agen perubahan terhadap manajemen talenta serta berdampaknya pada kinerja manajer hotel berbintang di Bali dapat diterima.

Pengaruh peran mitra strategis dan agen perubahan terhadap manajemen talenta serta dampkanya pada kinerja manajer hotel berbintang di Bali adalah positif; artinya peran mitra strategis yang relatif tinggi atau tingkat peran mitra strategis manajer yang dirasakan pada tingkat yang relatif tinggi, peran agen perubahan yang relatif tinggi atau tingkat yang relatif tinggi; serta manajemen talenta yang relatif tinggi akan dapat menentukan kinerja manajer hotel berbintang di Bali yang lebih tinggi.

Tabel 3: Rangkuman Hasil Pengaruh Peran Mitra Strategis Dan Agen Perubahan Terhadap Manajemen Talenta Serta Dampaknya Pada Kinerja Manajer.

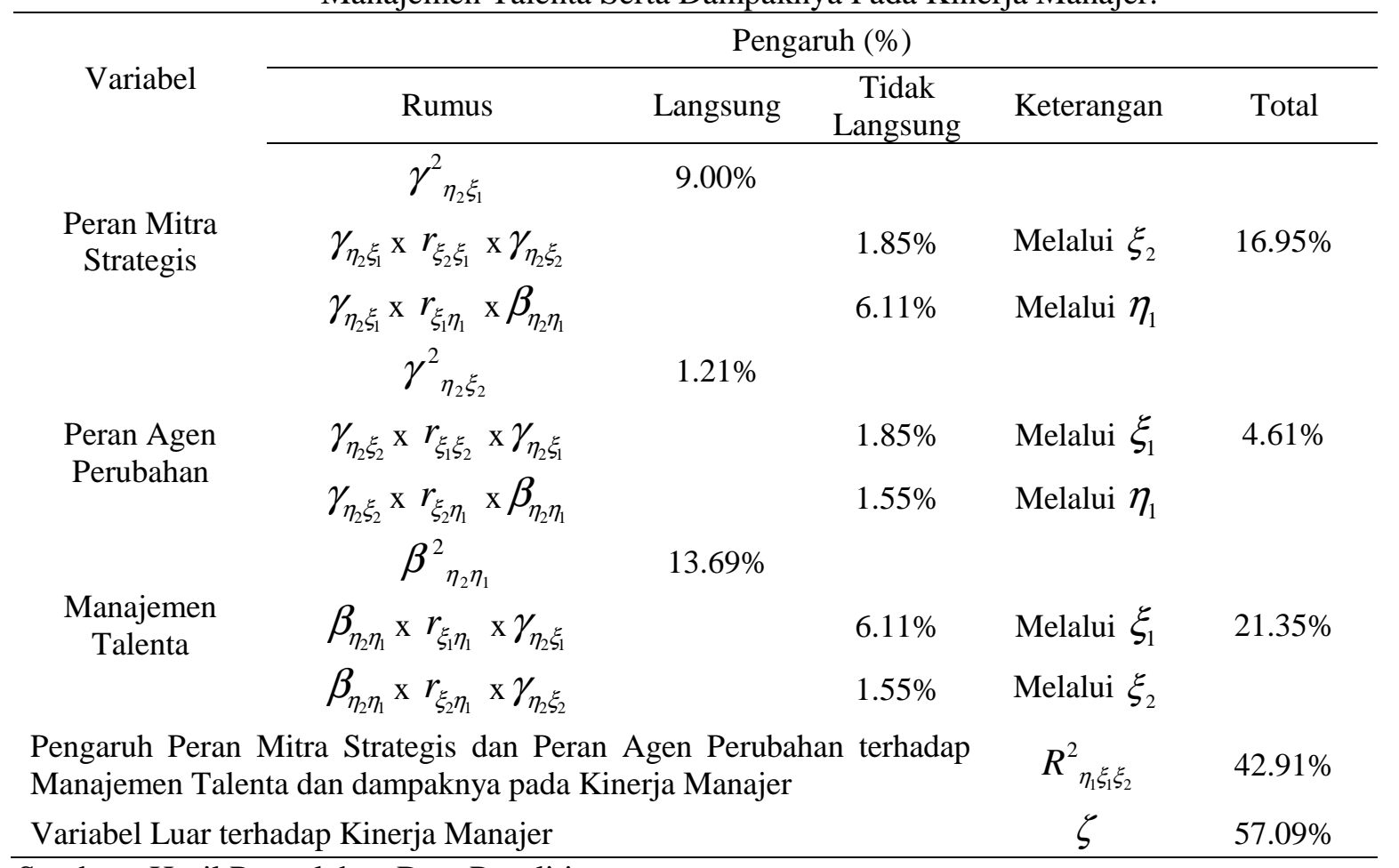

Sumber : Hasil Pengolahan Data Penelitian. 
Pengaruh variabel lain terhadap kinerja manajer yang ditunjukkan oleh epsilonnya $(\zeta)$ yaitu sebesar $57.09 \%$; hal ini mengindikasikan bahwa masih terdapat variabel lainnya yang turut serta mempengaruhi kinerja manajer pada hotel berbintang di Bali di luar variabel peran mitra strategis dan peran agen perubahan serta manajemen talenta yang memerlukan penelitian lebih lanjut. Berdasarkan ketiga pengaruh tersebut yaitu variabel manajemen talenta paling besar pengaruhnya terhadap kinerja manajer hotel berbintang yaitu sebesar $21.35 \%$ dibandingkan dua variabel lainnya yakni pengaruh peran mitra strategis terhadap kinerja manajer adalah sebesar $16.95 \%$ diperoleh lebih besar dari pengaruh peran agen perubahan terhadap kinerja manajer adalah sebesar $4.61 \%$.

Berdasarkan penjelasan diatas, berarti terdapat pengaruh positif dan signifikan antara peran mitra strategis dan peran agen perubahan terhadap manajemen talenta serta berdampak pada kinerja manajer. Implikasi temuan penelitian dapat ditinjau dari sudut pandang teori manajemen sumber daya manusia menunjukkan bahwa terdapat pengaruh peran mitra strategis dan agen perubahan terhadap manajemen talenta serta berdampak pada kinerja manajer pada Hotel Berbintang di Bali. Berarti semakin baik pelaksanaan peran mitra strategis dan agen perubahan manajer akan diikuti pula baiknya pelaksanaan manajemen talenta yang akan berdampak pada peningkatan kinerja manajer pada hotel berbintang di Bali. Ini berarti bahwa pihak manajemen hotel berbintang hendaknya meningkatkan peran mitra strategis dan agen perubahan serta pelaksanaan manajemen talenta dan melaksanakan evaluasi kinerja manajer. Temuan ini membuktikan bahwa pihak hotel berbintang harus memperhatikan peran mitra strategis dan agen perubahan dan manajemen talenta dalam meningkatkan kinerja manajernya. Hal ini sesuai dengan yang dikatakan Andrew and Matthew (2006) bahwa perubahan yang terjadi pada strategi hotel berbintang akan dapat berdampak pada pengelolaan strategi SDM. Oleh karenanya dibutuhkan kesesuaian fungsi strategi SDM dengan strategi hotel berbintang dengan tetap berperan menjadi agen perubahan. Pengelolaan peran SDM sebagai mitra strategis dan agen perubahan akan secara signifikan mempengaruhi kegiatan pengelolaan talenta organisasi dan memberikan perhatian pada peningkatan kinerja SDM dan strategi organisasi serta nilai inti organisasi.

Dari sudut pandang manajerial, temuan penelitian ini menunjukkan bahwa semakin baik pelaksanaan peran mitra strategis dan agen perubahan manajer diikuti oleh semakin baiknya pelaksanaan manajemen talenta serta terjadi peningkatan kinerja SDM pada hotel berbintang di Bali. Hubungan antara strategi SDM dengan strategi hotel hanya dapat dibuat dengan analisis perubahan lingkungan internal dan eksternal organisasi dalam peran sebagai agen perubahan pada bisnis. Untuk dapat berhasil, hotel berbintang di Bali memerlukan perencanaan SDM, seharusnya SDM tersebut berperan menjadi mitra strategis untuk mengembangkan keterampilan dan kompetensi bisnis. Perencanaan SDM yang strategis harus berdasarkan kepercayaan, sehingga dapat efektif dan mampu beradaptasi dengan cepatnya perubahan. Pada peran seperti ini manajer sebagai mitra strategis dan agen perubahan, karena pengelolaan SDM selalu berubah sebagai akibat adaptasi dan adopsi strategi hotel dalam menghadapi persaingan global. Peran mitra strategis dan agen perubahan ini merupakan faktor yang mempengaruhi pengelolaan talenta hotel berbintang dan memegang peran yang sangat signifikan dalam menghadapi tantangan kinerja SDM dan kinerja hotel berbintang di Bali untuk jangka panjang.

\section{PENUTUP}

Pelaksanaan peran mitra strategis manajer termasuk kategori cukup, hal ini berarti bahwa pelaksanaan peran manajer sebagai mitra strategis pada hotel berbintang di Bali masih perlu untuk ditingkatkan lagi agar di masa mendatang dapat mencapai kategori yang sangat tinggi. Dalam upaya meningkatkan kinerja manajer hotel berbintang di Bali perlu memberdayakan dan meningkatkan peran mitra strategis manajer agar menjadi lebih baik.

Pelaksanaan peran agen perubahan manajer termasuk kategori cukup, hal ini berarti bahwa pelaksanaan peran manajer sebagai agen perubahan pada hotel berbintang di Bali masih perlu untuk ditingkatkan lagi agar di masa mendatang dapat mencapai kategori yang sangat tinggi, yaitu dengan memberdaya- 
kan dan meningkatkan peran agen perubahan manajer agar menjadi lebih baik.

Partisipasi manajer dalam manajemen talenta termasuk kategori cukup, hal ini berarti bahwa partisipasi manajer dalam manajemen talenta pada hotel berbintang di Bali masih perlu untuk ditingkatkan lagi agar di masa mendatang dapat mencapai kategori yang sangat tinggi, yaitu dengan memberdayakan dan meningkatkan partisipasi manajer dalam pelaksanaan manajemen talenta agar menjadi lebih baik.

Partisipasi manajer dalam kinerja manajer termasuk kategori cukup, hal ini berarti bahwa partisipasi manajer dalam kinerja manajer pada hotel berbintang di Bali masih perlu untuk ditingkatkan lagi agar di masa mendatang dapat mencapai kategori yang sangat tinggi, yaitu dengan menerapkan penilaian kinerja manajer di samping dilakukan atasan juga dilakukan rekan sekerja, bawahan dan pengguna jasa, dalam hal ini adalah wisatawan, dimaksudkan untuk menghindari subjektivitas penilaian, dan hasil penilaian tersebut diberikan sebagai umpan balik kepada hotel berbintang untuk dikelola dan ditindaklanjuti bagi kepentingan pencapaian tujuan organisasi.

Terdapat pengaruh positif dan signifikan antara peran mitra strategis dan peran agen perubahan terhadap manajemen talenta serta berdampak pada kinerja manajer. Berarti semakin baik pelaksanaan peran mitra strategis dan agen perubahan manajer akan diikuti pula baiknya pelaksanaan manajemen talenta yang akan berdampak pada peningkatan kinerja manajer pada hotel berbintang di Bali. Temuan ini membuktikan bahwa pihak hotel berbintang harus memperhatikan peran mitra strategis dan agen perubahan manajer dan manajemen talenta dalam meningkatkan kinerja manajernya. Oleh karenanya dibutuhkan kesesuaian fungsi strategi SDM dengan strategi hotel berbintang dengan tetap berperan menjadi agen perubahan. Pengelolaan peran SDM sebagai mitra strategis dan agen perubahan akan secara signifikan mempengaruhi kegiatan pengelolaan talenta organisasi dan memberikan perhatian pada peningkatan kinerja SDM dan strategi organisasi serta nilai inti organisasi.

\section{DAFTAR PUSTAKA}

Alison C., E. Jeff., K. Suzanne., R. Louise., R. Mark. And S. Rajesh. 2006. Talent
Management Supplement. Oracle HRMS. Release 11 and 12. December.

Amy H. 2007. Talent Management FAQ, httn://www.hrworld.com/whitepaper/d iinitive-itm-guidel] Diakses taggal 20 November 2007.

Andrew M. 2005. Helping HR to Understand the Strategic Value Chain, Strategic HR Review Chicago: Nov/Dec 2005. 5 (1). $32-44$.

Andrew. NG. and PJ. Matthew. 2006. Leadership Competencies: An

Introduction, Lournal of Healthcare Management, Chicago: Jan/Feb 2006. 51 (1). 13 - 18.

Ann. P. 2007. C-Suite Worries Over Succession Planning, HR Magazine Alexandria: Dec 2007 2 (I). 12-22.

Anne. K. 2002. Partners for change, CA Magazine. Toronto: an/Feb 2002 135 (1). 1-33.

Anita, MM. 2009. How Industries Evolve Principles Performance Boston University School of Management, http://www.amazon.com/. Diakses tanggal 29 September 2009.

Anonymous. 1999. People are assets, too, Business Asia. New York: Eep 6.1999. 31 (1). 1-18.

Anonymous. 2005. The Top HR Issues for 2005, HR Focus New York: Jan 2005. 82 (1). 1-2.

Anonymous. 2006. Many Actions Add Up to Successful Talent Management, HR Focus New York: ul 2006. 83 (7).3-5.

Anonymous. 2006. Influence decisions as an HR business partner, Strateoic $H R$ Review Chicago: an/Feb 2006 5 2). 5

Anonymous. 2007. Take Talent Management to the Next Level, HR Focus. New York: Nov 2007. 84 (11). 1-4.

Armstrong, M. 2006. Strategic Human Resource Management : a Guide to Action. USA.Thomson-Shore, Inc.

Berger, L.A. and Berger, D.R. 2003. The Talent Management Handbook: Creating 
Organizational Excellence by Identifying, Developing, and Promoting Your Best People. New York. McGraw Hill.

Benardin, HJ and JEA, Russel. 2003. Human Resource Management. Second Edition. New York: McGraw-Hill.

Bernadette, S. and R, Sheetal. 2008. Talent management in hospitality: graduate career success and strategies, $U K$ International Journal of Contemporary Hospitality Management. 20 (7). 781791.

Bill, D. and W. Marcus. (2007), Talent Management for Dummies, Indianapolis, USA: Wiley Publishing, Inc.

Bob, B. 2004. Critical success factors in UK budget hotel operations, International Journal of Operations and Production Management. 24 (9). 944-969.

Boudreau, JW. 2003. Sustainability and the Talentship Paradigm: Strategic Human Resource Management Beyond the Bottom Line, Center for Advanced Human Resource Studies (CAHRS), CAHRS Working Paper Series, Cornell University.

Boudreau, JW. and MR. Peter. 2007. Beyond HR: the new science of human capital, USA: Harvard Business School.

Carol B. 2004. Build a Talent Strategy to achieve your desired business results, Handbook of Business Strategy.133139.

Cascio, WF. 2006. Managing Human Resources: Productivity, Quality of Work Life, Profits, Seventh Edition, New York : Mc. Graw Hill, Irwin.

Cheryl. F. 2005. HR's role in talent management and driving business results, Emplovment Relations Todav Hoboken: \$pring 2005. 32 (1).55-62.

Chris, A. 2007. Don't forget that expertise is only a means to an end, American Agent and Broker. St. Louis. 79 (2); 14-16.
Chris, W. 2007. Matching supply to demand A strategic approach to talent management, Hay Group's UK Talent Practice Leader, chris_watkin@ haygroup.com, dd +44 (0)20 7856 7310 .

Christensen, R. 2006. Roadmap to strategic HR : turning a great idea into a business reality. USA. New York. AMACOM.

Cindv. M and W. Michael 2006. Talent Management in the 21st Century: Help Your Company Find, Develop, and Keep its Strongest Workers, The Vournal for Ouality and Participation. Cincinnati. 29 (4). 4-9.

Dan-Shang, W. and S. Chi-Lih. 2008. Will the strategic fit between business and HRM strategy influence HRM effectiveness and organizational performance?, International Journal of Manpower.. 29 (2). 92-110.

David. F 2007. Advanced TM, .Leadership Excellence Provo. 24 (11). 14-15.

David. S. 2007. Factors to Motivate Employee Performance, Rural Telecommunica ions Washington. 26 (3). 44-46.

Dessler, G. 2006. Human Resources Management, Ninth Edition, International Edition, Canada: Prentice Hall International Inc.

Don. S. and Darrvl M.2007. The 5 dragons that can burn your culture and how HR can be your strategic weapon, superVision. 68 (5). 9-12.

Dreher, G. 2001. Aligning HR with business goals, Surveys edition, Financial Limes London (UK). $\mathrm{ct} 2206$.

Michaels, E., H. Handfield-Jones and B. Axelrod. 2001. The War for Talent, Boston: Harvard Business School Press.

Edward. EL. 2005. From human resource management to organizational effectiveness. Human Resource Management. Hoboken. 44 (2). 165170. 
Elissa.T, K.Tina and V. Nidhi 2005. NextGeneration Talent Management: Insights On How Workforce Trends Are Changing The Face Of Talent Management, Business Credit New York.107 (7). 20-28.

Fay, H. 2007. Control and Customization, Workforce Management. Costa Mesa. 86 (19). 42-42.

Eiona.E 2007. The benefits of partnership for OD and HR, Strategic HR Revien. Chicago. 6 (4). 32-36.

Gill, M., W. Sandra. and Q. Samantha. 2004. Quality service in the international hotel sector A catalyst for strategic human resource development?, Journal of European Industrial Training.28 (2/3/4). 159-182.

Gillian, AM. and M. Samantha. 2008. Talent management in hospitality and tourism in Scotland Operational implications and strategic actions, International Journal of Contemporary Hospitality Management, Glasgow Caledonian University. UK. Glasgow. 20(7). 820830.

Gomes, FB. 2001. Manajemen Sumber Daya Manusia Cetakan Kelima. Andi Offset. Yogyakarta.

Guy, L. and S. Ina. 2007. Talent management: a strategic imperative, Ashridge Business School. http://www.ashridge.org.uk. Diakses 12 Agustus 2008

Hair, JF.Jr., RE. Anderson., LT.Ronald. and CB. William. 2006. Multivariate Data Analysis. $7^{\text {th }}$ edition. London: Prentice Hall International Inc.

Hammer, M. and J. Champy. 2003. Reengineering the corporation: A manifesto for business revolution. New York: Harper Collins.

Helen, A. and BB. Jackie. 2001. Rethinking performance measures: assessing progress in UK hotels. International Journal of Contemporary Hospitality Management. MCB University Press. 128-135
Howard. R. 2007. Fostering a PerformanceDriven Culture in the Public Sector, Public Manager Potomac.36 (3). 5157.

Hubert R. 2006. Change your organization, start with yourself, Training and Management Development Methods. Bradford. 20 (4;). 437-449.

Ian, C. 2007. Talent management: making it real, Development and Learning in Organizations 21 (2). 4-6.

Ivancevich, JM. 2006. Human Resources Management, Ninth edition, Toronto: Mc. Graw Hill, Irwin,.

Jeanette, L. 2009. From administrative expert to strategic partner, Employee Relations. 31(2). 182-196.

oan. EP 2004. The Implementation of Workforce and Succession Planning in the Public Sector, Public Personnel Management. Washington. 3 (4). 389395.

ohn._H_ 2005. Strategic HR means engaging staff, Canadian HR Reporten Toronto. 18 (15). 26-26.

Josh, B. (2008). Talent Management: State of the Industry, Bersin and Associates, Oakland, California: LRP Publications

udd, HM. L. Reiner. and AG. Mark. 2006. Production employee performance at a furniture manufacturer: The importance of supportive supervisors, Forest Products Journal Madison. 56 (6). 1925.

Julia, CH. and R. Evelina. 2008. Talent management: A strategy for improving employee recruitment, retention and engagement within hospitality organizations, International Journal of Contemporary Hospitality Management.. 20 (7). 743-757.

Jyotsna B. 2007. Talent management strategy of employee engagement in Indian ITES employees: key to retention, Employee Relations. 29 (6). 640-663. 
Karen D. 2007. Show off strategic skills in talent management, Personnel Todar. Sutton. 14-14.

Kathv G. 200.10 Steps for HR To Earn Its Seat at the Table, HR Magazine Alexandria: 51 (6). 44-44.

Lancourt, J. and C. Savage. 2005. Organizational Transformation and The Changing Role of The Human Resource Function, Compensation and Benefits Management. Autumn. 42-49.

Laurie B. 2007. BPM's Missing Link, Business Finance Loveland. 13 (10). 45-49.

Lea. NS 2004. Prepare for the Future, Executive Excellence Provo. 21 (11). 15-17.

Lorenzo, JH. 2005. The Impact of Talent Management on Organization Performance: A Persfective of The Resource-Based View of the Firm, Nova Southeastern University.

Malcolm. H. 2006. Building employee engagement, Manager Undate Henleyon-Thames. 18 (2). 31

Marcus P. and L, Guv L 2007. Courage in the face of extraordinary talent, . Strategic HR Review Chicago. 6 (5). 24-28.

Margaret, DN. 2008. Talent management, work-life balance and retention strategies, International Journal of Contemporary

Management. 20 (7). 792-806.

Margaret, DN. 2001. Exploring the Effect of A Climate fro Service on the SHRM Firm performance Relationship, University of Colorado

Matthew, G., BL. Asmus. and L. Emily. 2006. The People Problem in Talent Management, The McKinsey Quarterly, Number 2.

May, H., B. Yvette., H. Ben., J. Chandana. and B. Wismore. 2004. Current human resource challenges in the Caribbean hospitality Industry, International Journal of Contemporary Hospitality Management. 16 (7). 415-418.
McCracken, M. and M. Wallace. 2000. Toward a redefinition of strategic HRD, Journal of European Industrial Training.

Mello, JA. 2002. Strategic Human Resource Management, South-Western, Ohio, USA: Thompson Learning

Mohinder, C. and AK. Anastasia. 2007. The impact of HRM practices on organisational performance in the Indian hotel industry, Employee Relations.. 29 (6). 576-594.

Michael, CGD. 2003. Does Organizational climate add to service quality in hotels?, International Journal of Contemporary Hospitality Management. 15 (4). 206-213

Michael, R. 2007. Managing tomorrow's people The future of work to 2020, Partner and leader of Human Resource, Services Price waterhouse Coopers LLP.

Michiel, S. and J. Jan. 2005. Managing intangible assets An essay on organising contemporary organisations based upon identity, competencies and networks, Journal of Management Development. 24 (6). 506-518

Mine, H. and H. Peter. 2005. Performance measurement practice in an independent hotel context A case study approach, International Journal of Contemporary Hospitality Management. 17 (1). 39-50.

Noe., Hollenbeck., Gerhart. and Wright. 2006. Human Resources Management: Gaining a Competitive Advantage, Fifth edition, New York: Mc. Graw Hill, Irwin

Norma, D. 2008. Managing the talent management pipeline Towards a greater understanding of senior managers' perspectives in the hospitality and tourism sector, International Journal of Contemporary Hospitality Management. 20 (7). 807819. 
Parminder S. 2009. Talent Management a key business process, www.citehr.com Diakses 10 Agustus 2009

Paul, B. 2008. Education and talent management: implications for the hospitality industry School of Marketing, Tourism and Languages, International Journal of Contemporary Hospitality Management. 20 (7). 730742.

Paul, JP. 2002. Efficacy of Human Resources as Change Agents, Walden University.

Paul.SK 2003. Management development: In search of a new role? The Journal of Management Development. 22 (1/2). 171-181.

Pauline, C. and M. Geraldine. 2007. High performance work practices and competitive advantage in the Irish hospitality sector, International Journal of Contemporary Hospitality Management. 19 (3). 201-210.

Peter FD 2004. The Way Ahead, Executive Excellence Provo. 21 (5). 3-3.

Peters, T. 2006. Leaders As Talent Fanatics, Leadership Excellence Provo. 23 (11).. $12-14$.

Phil. S. and T. Shaun. 2005. The talent challenge, Personnel Todav Sutton. Jun 28. 15-15.

Philmore, A., D. Liz. and G. Dion. 2006. Approaches to HRM in the Barbados hotel industry, International Journal of Contemporary Hospitality Management. 18 (2). 94-109.

Rakesh, S. and B. Jyotsna. 2009. Talent management-competency development :key to global leadership, Industrial and Commercial Training. 41(3). 118132

Rebecca, C. 2006. Reflections on Talent Management, Change agenda, Shaping HRD for the new millennium. Human Resource Development Ouarterly San Francisco. 12 (2). 103-105
Robbins, SP. 2006. Organizational Behavior. $10^{\text {th }}$ Edition. New Jersey: PrenticeHall, Inc

Kod. N. 2007. Investing in an uncertain future, Financial Times. UK.London. 3

Eammi. S. 2004. Beyond the Rainbow, Association Management. 56 (4). 2633.

Sandra, W. 2008. Where are we now? A review of management development issues in the hospitality and tourism sector Implications for talent management, International Journal of Contemporary Hospitality Management. 20 (7). 758780.

Sharon. B. 2007. The art of business partnering, Strategic HR Review Chicago. 6 (6). $32-36$

Sparrow, P., B. Chris. and H. Hilary. 2004. Globalizing human resource management. USA. New York. Taylor and Francis e-Library

Stephen._H. and O.Colleen 2004. Managing talent to maximize performance, Emplovment Relations Todav. 31 (2). 67.

Susan.H. 2007. Performance Appraisals Don't Work-What Does?, The Journal for Duality and Participation. Cincinnati. 30 (1). 6-11.

Taleo. 2006. Customers Achieve Dramatic Improvements in Business Performance With Talent Management, PR Newswire. New York. Ju 25.

Tom, B. 2008. Implications of hospitality and tourism labour markets for talent management strategies, International Journal of Contemporary Hospitality Management. 20(7). 720-729.

Ulrich, D. 1997. Human Resources Champion: The Next Agenda for Adding value and delivering Results, Boston: Harvard Business Shool Press.

Watson, WW. 2007. Study of HR best practices, available at: www. watson wyatt.com. Diakses tanggal 16 april 2007. 


\section{Lampiran 1}

Tabel Hasil Skoring Peran Mitra Strategis Manajer

\begin{tabular}{|c|c|c|c|c|}
\hline $\begin{array}{l}\text { Sub Variabel } \\
\text { Peran Mitra } \\
\text { Strategis }\end{array}$ & Dimensi & Indikator & Skor & Kategori \\
\hline \multirow[t]{3}{*}{$\begin{array}{l}\text { Fokus pada } \\
\text { pelanggan }\end{array}$} & $\begin{array}{l}\text { Memahami } \\
\text { pentingnya } \\
\text { memberikan }\end{array}$ & $\begin{array}{l}\text { Tingkat partisipasi manajer dalam } \\
\text { memberikan kepuasan pelanggan } \\
\text { hotel }\end{array}$ & 1352 & Cukup \\
\hline & $\begin{array}{l}\text { pelayanan yang baik } \\
\text { kepada pelanggan }\end{array}$ & $\begin{array}{l}\text { Tingkat partisipasi manajer } \\
\text { menanggapi keluhan dan permintaan } \\
\text { pelanggan }\end{array}$ & 1367 & Tinggi \\
\hline & \multicolumn{2}{|c|}{ Total Fokus pada pelanggan } & 2719 & Cukup \\
\hline \multirow[t]{2}{*}{$\begin{array}{l}\text { Budaya dan } \\
\text { kepemimpinan }\end{array}$} & $\begin{array}{l}\text { Konsistensi dan } \\
\text { efektivitas pimpinan }\end{array}$ & $\begin{array}{l}\text { Tingkat partisipasi manajer dalam } \\
\text { mengikuti perintah kerja pimpinan }\end{array}$ & 1425 & Tinggi \\
\hline & $\begin{array}{l}\text { Pelaksanaan budaya } \\
\text { kerja }\end{array}$ & $\begin{array}{l}\text { Tingkat partisipasi manajer atas } \\
\text { penekanan pimpinan pada budaya } \\
\text { kerja }\end{array}$ & 1302 & Cukup \\
\hline \multicolumn{3}{|c|}{ Total Budaya dan kepemimpinan } & 2727 & Tinggi \\
\hline \multirow[t]{2}{*}{$\begin{array}{l}\text { Supervisi } \\
\text { karyawan }\end{array}$} & $\begin{array}{l}\text { Konsistensi dan } \\
\text { efektivitas kerja }\end{array}$ & $\begin{array}{l}\text { Tingkat partisipasi manajer pada } \\
\text { konsistensi supervisi hotel }\end{array}$ & 1388 & Tinggi \\
\hline & supervisi & $\begin{array}{l}\text { Tingkat partisipasi manajer pada } \\
\text { efektivitas supervisi }\end{array}$ & 1440 & Tinggi \\
\hline \multicolumn{3}{|c|}{ Total Supervisi karyawan } & 2828 & Tinggi \\
\hline \multirow[t]{2}{*}{$\begin{array}{l}\text { Lingkungan } \\
\text { kerja }\end{array}$} & $\begin{array}{l}\text { Kondisi lingkungan } \\
\text { kerja }\end{array}$ & $\begin{array}{l}\text { Tingkat partisipasi manajer } \\
\text { merencanakan perubahan dan } \\
\text { perbaikan lingkungan kerja }\end{array}$ & 1340 & Cukup \\
\hline & \multicolumn{2}{|c|}{ Total Lingkungan Kerja } & 1340 & Cukup \\
\hline \multirow[t]{3}{*}{$\begin{array}{l}\text { Keterlibatan } \\
\text { karyawan dan } \\
\text { timwork }\end{array}$} & Kerjasama tim & $\begin{array}{l}\text { Tingkat partisipasi manajer dalam } \\
\text { pemecahan masalah dan pengambilan } \\
\text { keputusan }\end{array}$ & 1444 & Tinggi \\
\hline & $\begin{array}{l}\text { Keterlibatan kerja } \\
\text { karyawan }\end{array}$ & $\begin{array}{l}\text { Tingkat partisipasi manajer dalam } \\
\text { persahabatan dengan sesama rekan } \\
\text { kerja }\end{array}$ & 1373 & Tinggi \\
\hline & \multicolumn{2}{|c|}{ Total Keterlibatan karyawan dan Timwork } & 2817 & Tinggi \\
\hline \multirow[t]{2}{*}{$\begin{array}{l}\text { Pelatihan dan } \\
\text { pengembangan }\end{array}$} & Pelatihan karyawan & $\begin{array}{l}\text { Tingkat partisipasi manajer dalam } \\
\text { pelatihan }\end{array}$ & 1319 & Cukup \\
\hline & $\begin{array}{l}\text { Pengembangan } \\
\text { karyawan }\end{array}$ & $\begin{array}{l}\text { Tingkat partisipasi manajer terhadap } \\
\text { program pengembangan }\end{array}$ & 1320 & Cukup \\
\hline \multicolumn{3}{|c|}{ Total Pelatihan dan pengembangan } & 2639 & Cukup \\
\hline $\begin{array}{l}\text { Evaluasi dan } \\
\text { perbaikan }\end{array}$ & Penilaian kinerja & $\begin{array}{l}\text { Tingkat partisipasi manajer dalam } \\
\text { penilaian kinerja }\end{array}$ & 1277 & Cukup \\
\hline kinerja & Perbaikan kinerja & $\begin{array}{l}\text { Tingkat partisipasi manajer dalam } \\
\text { perbaikan kinerja }\end{array}$ & 1330 & Cukup \\
\hline \multicolumn{3}{|c|}{ Total Evaluasi dan perbaikan kinerja } & 2607 & Cukup \\
\hline $\begin{array}{l}\text { Faktor-faktor } \\
\text { pemilihan }\end{array}$ & $\begin{array}{l}\text { Pemilihan organisasi } \\
\text { sebagai tempat kerja }\end{array}$ & $\begin{array}{l}\text { Tingkat partisipasi manajer atas } \\
\text { pemilihan tempat bekerja }\end{array}$ & 1308 & Cukup \\
\hline \multicolumn{3}{|c|}{ Total Faktor pemilihan pekerjaan } & 1308 & Cukup \\
\hline Iklim pelayanan & $\begin{array}{l}\text { Kualitas pelayanan } \\
\text { kepada pelangan }\end{array}$ & $\begin{array}{l}\text { Tingkat partisipasi manajer dalam } \\
\text { peningkatan kompetensi pelayan }\end{array}$ & 1363 & Tinggi \\
\hline \multirow{2}{*}{\multicolumn{3}{|c|}{$\begin{array}{l}\text { Total Iklim pelayanan } \\
\text { Strategis Manajer }\end{array}$}} & 1363 & Tinggi \\
\hline & & & 20348 & Cukup \\
\hline
\end{tabular}

Sumber: Diolah dari data penelitian 


\section{Lampiran 2}

Tabel Hasil Skoring Peran Agen Perubahan Manajer

\begin{tabular}{|c|c|c|c|c|}
\hline $\begin{array}{l}\text { Sub Variabel } \\
\text { Peran Agen } \\
\text { Perubahan } \\
\end{array}$ & Dimensi & Indikator & Skor & Kategori \\
\hline $\begin{array}{l}\text { Menentukan } \\
\text { perubahan }\end{array}$ & $\begin{array}{l}\text { Pelaksanaan dalam } \\
\text { menentukan perubahan dalam } \\
\text { hotel }\end{array}$ & $\begin{array}{l}\text { Tingkat partispasi manajer } \\
\text { dalam isu dan tujuan } \\
\text { perubahan hotel }\end{array}$ & 2630 & Cukup \\
\hline \multicolumn{3}{|c|}{ Total Menentukan perubahan } & 2630 & Cukup \\
\hline $\begin{array}{l}\text { Mengelola } \\
\text { kendala } \\
\text { perubahan }\end{array}$ & $\begin{array}{l}\text { Pelaksanaan dalam mengelola } \\
\text { kendala perubahan dalam hotel }\end{array}$ & $\begin{array}{l}\text { Tingkat partisipasi manajer } \\
\text { untuk mengelola kendala } \\
\text { perubahan }\end{array}$ & 2598 & Cukup \\
\hline \multicolumn{3}{|c|}{ Total Mengelola kendala perubahan } & 2598 & Cukup \\
\hline $\begin{array}{l}\text { Pendekatan } \\
\text { Identifikasi } \\
\text { implementasi } \\
\text { perubahan }\end{array}$ & $\begin{array}{l}\text { Mengidentifikasi pelaksanaan } \\
\text { program perubahan dalam } \\
\text { hotel }\end{array}$ & $\begin{array}{l}\text { Tingkat partisipasi manajer } \\
\text { mengidentifikasi implementasi } \\
\text { dan dampak perubahan }\end{array}$ & 2625 & Cukup \\
\hline \multicolumn{3}{|c|}{ Total Pendekatan Identifikasi implementasi perubahan } & 2625 & Cukup \\
\hline $\begin{array}{l}\text { Meningkatkan } \\
\text { dukungan untuk } \\
\text { berubah }\end{array}$ & $\begin{array}{l}\text { Upaya meningkatkan } \\
\text { dukungan untuk melaksanakan } \\
\text { perubahan dalam hotel }\end{array}$ & $\begin{array}{l}\text { Tingkat partisipasi manajer } \\
\text { menimgkatkan dukungan } \\
\text { terhadap perubahan }\end{array}$ & 1316 & Cukup \\
\hline \multicolumn{3}{|c|}{ Total Meningkatkan dukungan berubah } & 1316 & Cukup \\
\hline $\begin{array}{l}\text { Mengembangka } \\
\text { n sasaran } \\
\text { perubahan }\end{array}$ & $\begin{array}{l}\text { Kegiatan mengembangkan } \\
\text { sasaran-sasaran perubahan } \\
\text { dalam hotel }\end{array}$ & $\begin{array}{l}\text { Tingkat partisipasi manajer } \\
\text { mengidentifikasi dan } \\
\text { menyiapkan sasaran perubahan }\end{array}$ & 2672 & Cukup \\
\hline \multicolumn{3}{|c|}{ Total Mengembangkan sasaran perubahan } & 2672 & Cukup \\
\hline $\begin{array}{l}\text { Menciptakan } \\
\text { budaya yang } \\
\text { sesuai }\end{array}$ & $\begin{array}{l}\text { Kegiatan untuk menciptakan } \\
\text { perubahan budaya yang sesuai } \\
\text { dalam hotel }\end{array}$ & $\begin{array}{l}\text { Tingkat partisipasi manajer } \\
\text { dalam mengembangkan cara } \\
\text { untuk mengelola budaya dan } \\
\text { konflik dalam hotel }\end{array}$ & 2699 & Cukup \\
\hline \multicolumn{3}{|c|}{ Total Menciptakan budaya yang sesuai } & 2699 & Cukup \\
\hline $\begin{array}{l}\text { Membangun } \\
\text { kapasitas } \\
\text { sebagai agen } \\
\text { perubahan }\end{array}$ & $\begin{array}{l}\text { Kegiatan untuk membangun } \\
\text { kapasitas sebagai agen } \\
\text { perubahan dalam hotel }\end{array}$ & $\begin{array}{l}\text { Tingkat partisipasi manajer } \\
\text { membangun kapasitas sebagai } \\
\text { agen perubahan }\end{array}$ & 2626 & Cukup \\
\hline \multicolumn{3}{|c|}{ Total Membangun kapasitas sebagai agen perubahan } & 2626 & Cukup \\
\hline $\begin{array}{l}\text { Perencanaan } \\
\text { motivasi }\end{array}$ & $\begin{array}{l}\text { Merencanakan program untuk } \\
\text { memotivasi karyawan dalam } \\
\text { hotel }\end{array}$ & $\begin{array}{l}\text { Tingkat partisipasi manajer } \\
\text { dalam rencana motivasi }\end{array}$ & 2618 & Cukup \\
\hline \multicolumn{3}{|c|}{ Total Perencanaan motivasi } & 2618 & Cukup \\
\hline $\begin{array}{l}\text { Perencanaan } \\
\text { komunikasi }\end{array}$ & $\begin{array}{l}\text { Merencanakan proses } \\
\text { komunikasi dalam hotel }\end{array}$ & $\begin{array}{l}\text { Tingkat partisipasi manajer } \\
\text { mengembangkan komunikasi }\end{array}$ & 2613 & Cukup \\
\hline \multicolumn{3}{|c|}{$\begin{array}{l}\text { Total Perencanaan komunikasi } \\
\text { Perubahan Manajer }\end{array}$} & $\begin{array}{r}2613 \\
22397 \\
\end{array}$ & $\begin{array}{l}\text { Cukup } \\
\text { Cukup }\end{array}$ \\
\hline
\end{tabular}

Sumber: Diolah dari data penelitian 


\section{Lampiran 3}

Tabel Hasil Skoring Partisipasi Manajer dalam Manajemen Talenta

\begin{tabular}{|c|c|c|c|c|}
\hline $\begin{array}{c}\text { Sub Variabel } \\
\text { Manajemen } \\
\text { Talenta }\end{array}$ & Dimensi & Indikator & Skor & Kategori \\
\hline $\begin{array}{l}\text { Strategi } \\
\text { mempertahanka }\end{array}$ & $\begin{array}{l}\text { Pelaksanaan pogram } \\
\text { untuk mempertahankan }\end{array}$ & $\begin{array}{l}\text { Tingkat penerimaan manajer dalam } \\
\text { mengikuti nilai hotel }\end{array}$ & 1274 & Cukup \\
\hline n SDM & manajer & Tingkat kepuasan manajer & 2632 & Cukup \\
\hline \multicolumn{3}{|c|}{ Total Strategi mempertahankan SDM } & 3906 & Cukup \\
\hline \multirow{3}{*}{$\begin{array}{l}\text { Strategi } \\
\text { Pemilihan SDM }\end{array}$} & Pelaksanaan kegiatan & Tingkat ketatnya proses seleksi manajer & 1284 & Cukup \\
\hline & pemilina & $\begin{array}{l}\text { Tingkat keterbukaan proses rekrutmen } \\
\text { manajer }\end{array}$ & 1329 & Cukup \\
\hline & & $\begin{array}{l}\text { Tingkat partisipas manajer dalam } \\
\text { keputusan seleksi }\end{array}$ & 1288 & Cukup \\
\hline \multicolumn{2}{|c|}{ Total Strategi Pemilihan SDM } & & 3901 & Cukup \\
\hline Strategi & Pelaksanaan program & Tingkat efektivitas pelatihan & & \\
\hline Pelatihan & pelatihan manajer & yang diadakan & 3923 & Cukup \\
\hline \multicolumn{3}{|c|}{ Total Strategi Pelatihan Karyawan } & 3923 & Cukup \\
\hline SDM yang ada & Pengembangan karir & Tingkat kepedullian hotel memberikan & & \\
\hline \multirow[t]{2}{*}{ diorganisasi } & manajer & kesempatn promosi & 2609 & Cukup \\
\hline & & $\begin{array}{l}\text { Tingkat pertimbangan hotel dalam memilih } \\
\text { kandidat manajer }\end{array}$ & 1288 & Cukup \\
\hline \multicolumn{2}{|c|}{ Total SDM yang ada diorganisasi } & & 3897 & Cukup \\
\hline $\begin{array}{l}\text { Keinginan } \\
\text { manajer tetap }\end{array}$ & $\begin{array}{l}\text { Keinginan manajer } \\
\text { tetap }\end{array}$ & $\begin{array}{l}\text { Tingkat keinginan manajer untuk tetap } \\
\text { bekerja }\end{array}$ & 1296 & Cukup \\
\hline $\begin{array}{l}\text { bekerja di } \\
\text { organisasi }\end{array}$ & bekerja di hotel & $\begin{array}{l}\text { Tingkat keinginan manajer untuk tidak } \\
\text { keluar dari pekerjaan. }\end{array}$ & 1285 & Cukup \\
\hline \multicolumn{2}{|c|}{ Total Keinginan manajer tetap bekerja } & & 2581 & Cukup \\
\hline Penerimaan & Penerimaan manajer & Tingkat peneriman manajer pada kualitas & 1329 & Cukup \\
\hline $\begin{array}{l}\text { Kinerja } \\
\text { organisasi }\end{array}$ & Terhadap kinerja hotel & $\begin{array}{l}\text { Tingkat penyampaian informasi produk } \\
\text { baru, pelayanan baru dan program baru }\end{array}$ & 1292 & Cukup \\
\hline \multicolumn{2}{|c|}{$\begin{array}{l}\text { Total Penerimaan Kinerja organisasi } \\
\text { Total Manajemen Talenta }\end{array}$} & & $\begin{array}{c}2621 \\
20829\end{array}$ & $\begin{array}{l}\text { Cukup } \\
\text { Cukup }\end{array}$ \\
\hline
\end{tabular}

Sumber: Diolah dari data penelitian 


\section{Lampiran 4}

Tabel Hasil Skoring Kinerja Manajer

\begin{tabular}{|c|c|c|c|c|}
\hline $\begin{array}{c}\text { Sub Variabel } \\
\text { Kineria Manajer }\end{array}$ & Dimensi & Indikator & Skor & Kategori \\
\hline $\begin{array}{l}\text { Jumlah } \\
\text { pekerjaan }\end{array}$ & $\begin{array}{l}\text { Jumlah pekerjaan yg } \\
\text { dikerjakan manajer }\end{array}$ & $\begin{array}{l}\text { Tingkat kesesuaian jumlah dari pekerjaan yang } \\
\text { dilakukan manajer sesuai jumlah dan waktu } \\
\text { pekerjaan yang ditentukan }\end{array}$ & 2643 & Cukup \\
\hline \multicolumn{3}{|c|}{ Total Jumlah pekerjaan } & 2643 & Cukup \\
\hline $\begin{array}{l}\text { Kualitas } \\
\text { pekerjaan }\end{array}$ & $\begin{array}{l}\text { Kualitas pekerjaan } \\
\text { yang dikerjakan } \\
\text { manajer }\end{array}$ & $\begin{array}{l}\text { Tingkat kesesuaian mengenai akurasi dan } \\
\text { kesempurnaan pekerjaan sesuai standar kualitas } \\
\text { yang ditentukan }\end{array}$ & 2597 & Cukup \\
\hline \multicolumn{3}{|c|}{ Total Kualitas pekerjaan } & 2597 & Cukup \\
\hline $\begin{array}{l}\text { Pemahaman } \\
\text { prosedur kerja }\end{array}$ & $\begin{array}{l}\text { Pemahaman prosedur } \\
\text { kerja oleh manajer }\end{array}$ & $\begin{array}{l}\text { Tingkat kejelasan pengetahuan, keterampilan dan } \\
\text { pemahaman mengenai informasi terkait dengan } \\
\text { bidang pekerjaan }\end{array}$ & 2766 & Tinggi \\
\hline \multicolumn{3}{|c|}{ Total Pemahaman prosedur kerja } & 2766 & Tinggi \\
\hline Kreativitas & $\begin{array}{l}\text { Kreativitas manajer } \\
\text { dalam bekerja }\end{array}$ & $\begin{array}{l}\text { Tingkat kemampuan manajer mengembangkan } \\
\text { gagasan baru terkait dengan pekerjaannya }\end{array}$ & 2724 & Tinggi \\
\hline \multicolumn{3}{|c|}{ Total Kreativitas } & 2724 & Tinggi \\
\hline Kerjasama & $\begin{array}{l}\text { Kerjasama manajer } \\
\text { dalam bekerja }\end{array}$ & $\begin{array}{l}\text { Tingkat kemampuan untuk bekerjasama sesama } \\
\text { rekan sekerja, penyelia maupun bawahan }\end{array}$ & 2643 & Cukup \\
\hline \multicolumn{3}{|c|}{ Total Kerjasama } & 2643 & Cukup \\
\hline \multirow[t]{2}{*}{$\begin{array}{l}\text { Kemampuan } \\
\text { mendelegasikan } \\
\text { pekerjaan }\end{array}$} & $\begin{array}{l}\text { Kemampuan } \\
\text { mendelegasikan } \\
\text { pekerjaan }\end{array}$ & $\begin{array}{l}\text { Tingkat pemahaman manajer untuk mengikuti } \\
\text { petunjuk dan kebijakan perusahaan serta dapat } \\
\text { dipercaya. }\end{array}$ & 2621 & Cukup \\
\hline & \multicolumn{2}{|c|}{$\begin{array}{l}\text { dipercaya. } \\
\text { Totjaan Kemampuan mendelegasikan pekerjaan }\end{array}$} & 2621 & Cukup \\
\hline Inisiatif & $\begin{array}{l}\text { Inisiatif manajer dalam } \\
\text { bekerja }\end{array}$ & $\begin{array}{l}\text { Tingkat semangat dan keunggulan manajer untuk } \\
\text { melaksanakan tugas dan tanggung jawab sesuai } \\
\text { tugasnya }\end{array}$ & 2598 & Cukup \\
\hline & & al Inisiatif & 2598 & Cukup \\
\hline Kualitas pribadi & $\begin{array}{l}\text { Kualitas pribadi } \\
\text { manajer dalam bekerja }\end{array}$ & $\begin{array}{l}\text { Tingkat kemampuan dan kemajuan } \\
\text { kepemimpinan, sosialisasi, penampilan dan } \\
\text { integritas pribadi manajer }\end{array}$ & 2683 & Cukup \\
\hline \multicolumn{3}{|c|}{ Total Kualitas pribadi } & $\begin{array}{c}2683 \\
21275\end{array}$ & $\begin{array}{l}\text { Cukup } \\
\text { Cukup }\end{array}$ \\
\hline
\end{tabular}

Sumber: Diolah dari data penelitian 